O-301 福井医科大学 金丸洋史、三輪吉司、鈴木裕志、石田泰一、伊藤靖彦、 松田陽介、塩山力也、岡田謙一郎

【目的】1997 年に改訂された UICC の新しいTNM 分類では、 限局性腎癌について、腫瘍径 $7 \mathrm{~cm}$ 以下を $\mathrm{T} 1 、 7 \mathrm{~cm}$ を越える ものを T2 としている。今回、この分類の妥当性について、 検討をおこなった。【対象および方法】1983 年から1995年 までに手術を施行した、腎細胞癌 128 症例（男性 90 例、女 性 38 例）を対象とした。各症例の転帰および病理学的因子 について、旧分類 (1992 年版) と新分類との比較をおこなつ た。【結果】原発巣が腎内に限局していた 79 例の病期別症 例数と、それそれの 5 年疾患特異的生存率は、旧分類では T1 : 18 例 (5 年生存率 100\%), T2: 61 例 (90\%) であったのに対 して、新分類では T1：73 例 (92\%)，T2: 6 例 (100\%) となった。 全症例で腫瘍径とTNM カテゴリーとの関係を調べたところ、 $7 \mathrm{~cm}$ を越える腎癌は 128 例中 32 例あったが、そのうち T3 が 22 例、 T4 が 4 例であった。また、リンパ節転移は最小腫 瘍径 $3 \mathrm{~cm}$ から、遠隔転移は $5 \mathrm{~cm}$ から出現を認めた【考察】 新分類では、限局性腎癌の大多数が T1に分類され、 T1 は T 2 より予後不良であった。この原因として、第一に腫煌径 7c $\mathrm{m}$ を越える腎癌の多数は進行癌 (T3以上) であり、結果的に 悪性度の低い腫瘍のみが $\mathrm{T} 2$ 群として選択された可能性があ ること、第二に $7 \mathrm{~cm}$ 以下の腎癌には予後良好な症例と不良な 症例が混在していることが推測された。【結語】UICCの新 しいT分類は、問題点が多く、本邦での採用には慎重である ベきである。

\section{○-302 超音波督スクリーニング開始後の督癌長期成績} 関東中央病院

岡田洋平・小林 㴊? 岡 薰

【目的】超音波䟝スクリーニングにより発見された無症侯性腎癌 の長期予後を，同時期の有症候性腎癌と比較梌討した.

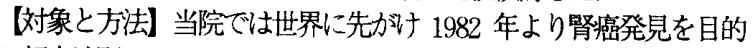
に超音波督スクリーニングを開始した。対象は 97 年 9 月までの無 症候群 86 例，有症候群 26 例 (DT1 - 3, N0, MO 症列)，観察期間は無 症候群 1-180 力月 (平均 67.5 力月), 有症候群 2.189 力月 (平均 64.3 力月)で，2群の相刘生存率，疾患特異的生存率，非再発率を梌討 したままた臨麻的，病理学的背景因子を検行した。

【結果】無症候群の内訳は $34-83$ 歳 (中央值59 藏), 男性61 例, 女 性 25 例, 腫场径は 8-105m (平均 $41 \mathrm{~mm}$ ), 有症候群は $34-89$ 歳 (中央 值 65 歳), 男性 17 例, 女性9 例で, 腫䶍径は $13-100 \mathrm{~m}$ ( 平均 $61 \mathrm{~mm}$ ) であった. 15 年相对生存率活無症候群 $56.9 \%$, 有症候群 $68.4 \%$ と両 群間に有意差を諗めなかったが, 15 年疾患特異的生存率では無症 候群 $95.2 \%$, 有症候群 $83.7 \%, 15$ 年非再発率で蛅症候群 $87.1 \%$, 有症候群で $77.1 \%$ と雨群間々それぞれ有意差を認めた( $0<0.001$ ，

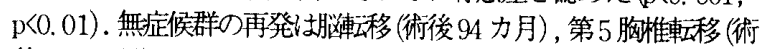
後 126 カ月) の 2 例で, 腫場径恃それぞれ $80 \mathrm{~mm}, 50 \mathrm{~mm}$ であった。 な打腫堭径 $50 \mathrm{~mm}$ 末渵(62例)の15 年非再発率は 10008 で, $50 \mathrm{~mm}$ 以上 (50例)の $74.4 \%$ と比一有意差を認めた(

【結論] 15 年疾患特異的生存率, 15 年非再発率加みて, 無症候 性腎癌の長期予後は有意に䭒好であった。しかし，無症候性でも $50 \mathrm{~mm}$ 以上の大きな腫場では経過中に邀隔転移を哂め，このような 症例では特に慎重な長期経過観察が必要と思われた。

\section{○-303 肾細胞嗇におけるグロボシリーズカンンクリオシド 発現の管床病理学的検討}

\author{
東北大学 \\ 斎藤誠一・佐藤信・大山力・伊藤明宏・高橋とし子・ \\ 折笠精一
}

【目的】手術により得られた腎癌原発巣 55 例、転移单 8 例 の凍結切片で、monosialosyl galactosyl globoside (MSGG) および disialosyl galactosyl globoside (DSGG) に対するモノクローナル抗体 RM1 およびRM2 を用い て免疫染色を施行した。切片の $10 \%$ 以上の染色反応を陽性、 全く染まらないものを陰性として、臨床病理学的な各種パラ メーターと統計学的に検討した。10\%末満の染色例は equivocal として統計学的な考察からは除いた。

【結果】原発巣 55 例中 34 例が RM1/RM2 陽性、15 例が RM1/RM2 陰性であった。RM1/RM2 陽性例は女性に比べ男性 で有意に多かった（p<0.001）。RM1/RM2 染色性は局所 浸润度や腫場サイズとの相関はみられなかった。平均腫場サ イズは RM1/RM2 陽性例 $(6.1 \mathrm{~cm})$ は陰性例 $(7.1 \mathrm{~cm})$ に比 して小さかった。Grade 3 は RM1/RM2 陽性例でのみ認めら れた。初診時および経過観察中の転移発生は RM1/RM2 陽性 例で有意に多かった $(\mathrm{p}<0.05)$ 。転移巣 8 例中 6 例が RM1/RM2 陽性であった。原発巣および転移巣ともに得られ た症例では転移巣で RM1/RM2 の染色反応が同等もしくはそ れ以上であった。

\section{O-304 掔級胞癌の症候の有無から見大臨床病理学的 検討}

帝京大学泌尿器科 ${ }^{1)} \cdot$ 同第 1 病理学教室 ${ }^{2)} \cdot$ 上尾中央病院 泌尿器科 ${ }^{3)}$ ・ 上山裕 ${ }^{1)}$ ・針生恭-1) - 岩㴊正之 ${ }^{1)}$ ・飯泉達 夫 1) ・ 矢崎恒忠 ${ }^{1)}$ - 梅田隆 1) . 入江宏 2) - 田中涉 3) - 佐藤 聡 3$) \cdot$ 村松弘志 3 )

【目的】画像検查で偶然発見される無症候性腎細胞癌 (偶 発癌) と有症候性の腎紐胞癌（症候癌）を臨床病理学的 に比較検討した。

【対象と方法】帝京大学付属病院および関連病院の腎細 胞癌症例 131 例を対象とした。病歴、手術記載、腫痬径 を測定し、病理組織は HE、PCNA (proliferative cell nuclear antigen)、 p 53 oncoprotein、 $\mathrm{T}$ 細胞、 B細胞で 染色して検討した。

【結果および考察】偶発癌 (68 例) と症候癌 (63 例) で 年齢分布には有意差はなかったが、死亡例は各々 2 例お よび 16 例で偶発癌が予後良好 $\left(x^{2}=6.63, \mathrm{p}<0.01\right)$ であ った。腫瘍径でも各々 $45 \pm 19 \mathrm{~mm} 、 65 \pm 29 \mathrm{~mm}$ と大き さに有意差 $(\mathrm{t}=2.62, \mathrm{p}<0.01)$ がみられた。病理学的に腫瘍 の組織学的異型度の頻度は両群に顕著な差はなかったが、 偶発癌は G1 (51\%)、症候癌では G2（33\%）がやや目 立った。PCNA、p 53 は主に症候癌の腫瘍部で染色され た。また、偶発癌では腫瘍部の間質にリンパ球浸潤（主 に T 細胞) が目立ち、腫瘍細胞が壊死になり瘢痕化した 病変が見られ、腫瘍の発育增殖が抑制されている可能性 が示唆された。アポトーシス細胞は検策した範田では数 例に観察されたのみでこの退縮過程に積極的に関与する 証拠はえられなかった。 